\title{
PERAN KUALITAS KEHIDUPAN KERJA DAN GRIT TERHADAP KETERIKATAN KERJA PADA GENERASI MILLENIAL DI INDUSTRI PERBANKAN
}

\author{
Stella Tiara ${ }^{1}$ dan Rostiana ${ }^{2}$ \\ ${ }^{1}$ Fakultas Psikologi, Universitas Tarumanagara \\ Email: ribkahtiara@gmail.com \\ ${ }^{2}$ Fakultas Psikologi, Universitas Tarumanagara \\ Email: dutaindah03@yahoo.com
}

\begin{abstract}
ABSTRAK
Dalam dua dekade terakhir, keterikatan kerja menjadi perhatian bagi dunia industri. Keterikatan kerja merupakan suatu keadaan pikiran yang positif terkait pekerjaan yang dicirikan dengan vigor, dedication, dan absorption. Keterikatan kerja pada penelitian ini dilihat dari sisi psikologi positif, sehingga peneliti tertarik untuk melihat peranan konsep psikologi positif seperti kualitas kehidupan kerja dan grit, yang merupakan konsep baru di Indonesia, terhadap keterikatan kerja. Partisipan dalam penelitian ini berjumlah 219 orang generasi millenial (N=219). Subyek yang bekerja di bank swasta berjumlah 109 orang dan 110 subyek yang bekerja di bank pemerintah. Penelitian ini menggunakan metode penelitian kuantitatif. Pengumpulan data menggunakan kuesioner yaitu Utrecht Work Engagement Scale (UWES) untuk keterikatan kerja, yang sudah divalidasi di banyak negara di dunia. Secara keseluruhan, hasil penelitian ini terlihat bahwa kualitas kehidupan kerja dan grit memiliki peranan positif terhadap keterikatan kerja. Kualitas kehidupan kerja memiliki peranan sebesar $29 \%\left(R^{2}=0.29, p<0.01\right)$ terhadap keterikatan kerja dan grit memiliki peranan sebesar $22 \%\left(R^{2}=0.22, p<0.01\right)$ terhadap keterikatan kerja.
\end{abstract}

Kata Kunci: keterikatan kerja, grit, kualitas kehidupan kerja, generasi millenial, perbankan

\section{PENDAHULUAN}

Keterikatan kerja (work engagement) telah menjadi perhatian bagi banyak pihak di dunia industri selama dua dekade terakhir karena dinilai dapat memberikan dampak positif bagi perusahaan. Hal ini didukung oleh beberapa penelitian yang telah menunjukkan bahwa karyawan yang engage membawa keuntungan bagi perusahaan karena dapat menampilkan performansi yang baik dalam bekerja (Demerouti \& Cropanzano, 2010; Christian, Garza \& Slaughter 2011). Karyawan yang memiliki keterikatan kerja yang tinggi memiliki tiga keuntungan. Pertama, mereka menjadi lebih bahagia dan antusias, sehingga dapat menghasilkan job resources yang akan berdampak pada penyelesaian tugas dengan hasil yang lebih baik. Kedua, mereka akan lebih sehat baik secara fisik maupun psikologis, sehingga karyawan dapat bekerja dengan lebih fokus dalam menyelesaikan pekerjaannya. Ketiga, mereka akan menyalurkan keterikatan kerja itu kepada karyawan lain, sehingga hubungan interpersonal dan kinerja kelompok dapat terjalin dengan baik (Bakker, 2011).

Karyawan yang memiliki keterikatan (engagement) tinggi hanya mengalami rata-rata sakit 2,69 hari per tahun dibandingkan dengan karyawan yang mengalami ketidakterikatan (disengagement) yang mengalami atau beralasan sakit dengan rata-rata 6,19 hari per tahun (Krisbiyanto, 2013). Secara umum rata-rata karyawan yang memiliki keterikatan kerja di wilayah Asia Pasifik menurun dari 60\% di tahun 2009 menjadi 56\% di tahun 2010. Penurunan tersebut merupakan kemunduran terbesar dalam 15 tahun terakhir (Hewitt, 2008). Dari beberapa penelitian mengenai keterikatan hampir seragam memberikan gambaran bahwa masalah keterikatan kerja di dunia saat ini masih sangat tinggi. Isu keterikatan ini juga sudah mulai diperhatikan di Indonesia. Di samping pertumbuhan bisnis yang kuat di Indonesia, rupanya keterikatan (engagement) atau loyalitas dan kesungguhan dalam bekerja yang dimiliki di Indonesia juga sangat rendah. Hasil survei dari Southeast Asian Nation (2013) menunjukkan bahwa Indonesia berada dalam urutan terbawah 
terkait mengenai engagement pada karyawan. Hasil tersebut menunjukkan bahwa hanya $8 \%$ dari karyawan Indonesia yang engaged terhadap pekerjaannya. Penelitian lainnya juga diadakan oleh Towers Watsons dalam Global Workforce Study (2014), hasilnya terlihat hampir sama. Dua pertiga karyawan di Indonesia tidak memiliki keterikatan yang tinggi terhadap pekerjaannya.

Keterikatan kerja pada dasarnya dipengaruhi oleh dua hal yaitu job resources dan personal resources. Job resources meliputi beberapa aspek seperti lingkungan fisik, sosial dan organisasi, gaji, peluang untuk berkarir, dukungan supervisor dan rekan kerja, serta umpan balik dari performa kerja (Schaufeli \& Bakker, 2003). Job resources yang beberapa diantaranya adalah variasi keahlian (skill variety), otonomi (autonomy), dan kesempatan untuk berkembang (developmental opportunities), kualitas kehidupan kerja (quality of work life) menjadi masalah penting dalam perusahaan karena dapat didefinisikan sebagai strategi tempat kerja yang mendukung dan memelihara kepuasan karyawan dengan tujuan untuk meningkatkan kondisi kerja karyawan dan organisasi. Kepuasan kerja karyawan kepada perusahaan dan dengan sendirinya merasa terikat (engaged) sehingga dapat pula membantu mengurangi keinginan karyawan untuk keluar dari perusahaan (Yadav \& Khanna, 2014).

Kebanyakan penelitian fokus pada hubungan kualitas kehidupan kerja dengan beberapa variabel seperti kepuasan kerja, komitmen organisasi, performa kerja, intensi pindah kerja, dan sebagainya yang memiliki peran penting dalam menentukan secara keseluruhan dari kesejahteraan organisasi. Pada penelitian yang dilakukan Alqarni (2016) menemukan bahwa seluruh dimensi kualitas kehidupan kerja memiliki hubungan yang positif dan signifikan dengan keterikatan kerja. Namun, masih kurangnya bukti-bukti empiris yang menghubungkan antara kualitas kehidupan kerja dengan keterikatan kerja (Kanten \& Sadullah, 2010). Hal ini menjadikan kualitas kehidupan kerja dan keterikatan kerja masih perlu diteliti kembali.

Selain job resources, keterikatan kerja juga dipengaruhi oleh personal resources yang meliputi keyakinan akan kemampuan diri (self-efficacy), rasa optimis (optimism), harapan mengenai masa depan (hope), dan resiliensi (resilience) (Schaufeli \& Bakker, 2003). Saat ini berkembang satu konsep baru lagi yang menggambarkan kepribadian seseorang yang memiliki gairah atau semangat (passion) dan ketekunan (perseverance) yang disebut dengan grit. Penelitian dari Von Culin, Tsukayama, dan Duckworth (2014), menyatakan bahwa grit berhubungan dengan pengejaran akan engagement (keterikatan dengan apa yang dikerjakan) dan makna dari hal yang dilakukan. Grit diikuti dengan bekerja keras menghadapi tantangan, mempertahankan usaha dan kepentingan jangka panjang meskipun dihadapkan pada resiko untuk gagal, tantangan, dan kesulitan pada prosesnya (Duckworth, 2016). Seorang dengan grit yang tinggi lebih berhasil dalam pekerjaan dibandingkan dengan yang memiliki grit rendah. Hasil penelitian Suzuki, Tamesue, Asahi, \& Ishikawa (2015) menunjukkan bahwa grit adalah prediktor yang kuat untuk performansi kerja dan juga performasi akademik. Individu dengan derajat grit yang tinggi akan lebih tekun dalam bekerja, tidak mudah menyerah jika mengalami kegagalan, bahkan dapat menjadikan kegagalan sebagai cambuk untuk semakin berusaha mencapai tujuan.

Hal lain yang menarik perhatian dalam beberapa tahun ini Indonesia juga memasuki masa era bonus demografi dimana penduduk produktif atau yang saat ini disebut dengan generasi millenial memiliki jumlah yang lebih banyak dari generasi sebelumnya (BPS, 2017). Generasi millenial sendiri dikenal dengan generasi yang memiliki kebiasaan kerja serta memiliki rasa optimis yang tinggi, fokus pada prestasi, percaya diri, percaya pada nilai-nilai moral dan sosial, serta menghargai adanya keragaman (Lancaster \& Stillman dalam Putra, 2016). Generasi millenial adalah generasi terbesar dalam sejarah dengan sekitar 79,8 juta anggota, melebihi jumlah generasi Baby Boomers 
(Robert Half International, 2008). Generasi millenial adalah generasi terbanyak yang masuk ke dalam dunia kerja. Masuknya generasi millenial ke dunia kerja menimbulkan konflik antar generasi yang signifikan. Generasi lain menganggap generasi millenial adalah generasi yang sulit dipahami dan memiliki stereotip tersendiri. Ada banyak kesalahpahaman tentang generasi millenial, Robert Half International (2008) melakukan studi bagaimana untuk merekrut dan mempertahankan karyawan generasi millenial.

Indonesia pada umumnya terdiri dari organisasi swasta dan organisasi pemerintahan, termasuk perbankan, yang menjadi urutan pertama dalam pertumbuhan ekonomi Indonesia sejak beberapa tahun belakangan ini (BPS, 2017). Industri perbankan merupakan salah satu industri yang mengedepankan kualitas pelayanan terhadap pelanggan yang tinggi. Smulder (dalam Schaufeli, 2011) menyatakan bahwa pekerjaan yang menuntut kualitas pelayanan sebagai modal utamanya membutuhkan keterikatan kerja yang tinggi. Penelitian mengenai keterikatan kerja karyawan membuktikan karyawan pada industri swasta, baik pada rumah sakit maupun universitas, memiliki tingkat yang lebih tinggi dibandingkan dengan karyawan yang ada di industri pemerintahan (Agyemang \& Ofei, 2013). Namun, dari penelitian yang terdahulu belum ada yang secara khusus meneliti dalam dunia perbankan.

Dengan latar belakang perkembangan ilmu serta beberapa perkembangan dalam dunia industri inilah peneliti tertarik untuk melihat secara khusus melihat peran grit dan kualitas kehidupan kerja terhadap keterikatan kerja pada generasi millenial dalam industri perbankan.

\section{METODE PENELITIAN}

Penelitian ini merupakan penelitian kuantitatif non eksperimen dengan pengolahan data menggunakan teknik regresi untuk melihat pengaruh variabel bebas terhadap variabel terikat tanpa mengubah keadaan atau mengubah perlakuan terhadap variabel yang diteliti. Dalam hal ini variabel terikatnya adalah keterikatan kerja. Variabel bebasnya adalah grit dan kualitas kehidupan kerja.. Jumlah partisipan pada penelitian ini adalah 219 orang yang bekerja sebagai pegawai bank swasta maupun pemerintah. Terdapat tiga kuesioner untuk mengukur masing masing variabel, dimana semua butir yang terdapat di kuesioner menggunakan bahasa Indonesia. Alat ukur yang digunakan berupa kuesioner grit, kualitas kehidupan kerja, dan keterikatan kerja. Data yang dapat disajikan dalam bentuk angka statistik dan dianalisa menggunakan program SPSS versi 23.

\section{Keterikatan kerja}

Pengukuran variabel keterikatan kerja ini menggunakan kuesioner Uthrect Work Engagement Scale (UWES-9) dari Schaufeli \& Bakker (2003). Kuesioner diisi menggunakan skala yang terdiri dari enam pilihan jawaban yaitu $1=$ tidak pernah sampai $6=$ sangat sering. Semakin tinggi skor yang diperoleh pada variabel ini, maka semakin sering mereka merasa terikat dengan pekerjaannya. Begitu pula hal ini berlaku sebaliknya. Kuesioner ini terdiri dari sembilan butir positif dan melalui hasil uji reliabilitas, diketahui bahwa keterikatan kerja memiliki koefisien alpha cronbach sebesar $0.826(\alpha=0.826)$. 


\section{Grit}

Kuesioner yang digunakan untuk mengukur variabel grit adalah kuesioner yang diterjemahkan oleh peneliti. Kuesioner grit pada penelitian ini terdiri dari 12 butir pernyataan. Kuesioner ini juga menggunakan skala Likert yang terdiri dari lima pilihan jawaban yaitu 1 = sangat tidak setuju sampai 5 = sangat setuju. Semakin tinggi skor yang diperoleh pada variabel ini, maka semakin tinggi grit yang dimiliki seseorang. Begitu pula hal ini berlaku sebaliknya. Hasil uji reliabilitas kuesioner grit memiliki koefisien alpha cronbach sebesar $0.807(\alpha=0.807)$.

\section{Kualitas Kehidupan Kerja}

Kuesioner yang digunakan untuk mengukur variabel kualitas kehidupan kerja adalah kuesioner yang sudah dibakukan dan dikembangkan oleh Bagian Riset dan Pengukuran Fakultas Psikologi Universitas Tarumanagara. Skala kualitas kehidupan kerja pada penelitian ini memiliki 47 butir pernyataan. Kuesioner ini menggunakan skala yang terdiri dari enam pilihan jawaban yaitu $1=$ tidak ada atau tidak tahu sampai $6=$ istimewa. Semakin tinggi skor yang diperoleh maka semakin tinggi tingkat kualitas kehidupan kerja seseorang. Begitu pula sebaliknya. Hasil uji reliabilitas kuesioner grit memiliki koefisien alpha cronbach sebesar $0.969(\alpha=0.969)$.

\section{HASIL DAN PEMBAHASAN}

Pengujian normalitas data dilakukan dengan melakukan uji distribusi data, dan dilanjutkan dengan melakukan uji normalitas terhadap tiga variabel penelitian. Uji normalitas data dilakukan dengan melakukan uji Saphiro-Wilk yang merupakan pengujian untuk jumlah sampel yang kecil $\mathrm{N} \geq 2,000$ (Garson, 2012).

Tabel 1

Gambaran Distribusi Data \& Normalitas Variabel

\begin{tabular}{lcccc}
\hline & Skewness & Kurtosis & Shapiro - Wilk & Interpretasi \\
\hline Keterikatan Kerja & -0.02 & -0.31 & $\mathrm{w}=0.99$ & data normal \\
Grit & -0.00 & -0.29 & $\mathrm{w}=0.99$ & data normal \\
Kualitas Kehidupan & 0.07 & -0.12 & $\mathrm{w}=0.99$ & data normal \\
Kerja & & & & \\
\hline
\end{tabular}

Pada hasil uji distribusi normal variabel keterikatan kerja, grit, dan kualitas kehidupan kerja terlihat ketiga variabel tersebut telah memenuhi syarat distribusi normal karena masih ada diantara ukuran $-1<$ skewness/kurtosis $<+1$, sehingga dapat disimpulkan bahwa data penelitian terdistribusi normal. Setelah data telah terdistribusi normal, maka pengolahan data dilanjutkan dengan melakukan uji normalitas dengan melakukan shapiro-wilk test. Hasil pengujian menghasilkan bahwa data variabel keterikatan kerja, grit, dan kualitas kehidupan kerja adalah normal. Hal ini ditunjukkan bahwa skor pada hasil pengujian shapiro-wilk test ketiga variabel tersebut adalah $p>0.05$.

Sebagai analisis hipotesis pertama mengenai peranan grit terhadap keterikatan kerja dilakukan uji regresi menggunakan program SPSS 23. Hasil uji dari data dengan menggunakan metode regresi linear diperoleh nilai $\beta=0.625$ dengan signifikansi $p \leq 0.01$. Hal ini menunjukkan bahwa terdapat peranan grit terhadap keterikatan kerja. Dari hasil uji regresi juga diperoleh nilai R sebesar 0.464 dan koefisien determinasi $\mathrm{R}^{2}$ ( $\mathrm{R}$ square) sebesar 0.215. Hal ini menunjukkan bahwa grit memberikan sumbangan peranan sebesar $21.5 \%$ terhadap keterikatan kerja. Grit yang dimiliki oleh para pekerja millennial yang ada di industri perbankan Indonesia mempengaruhi keterikatan kerja yang mereka miliki. 


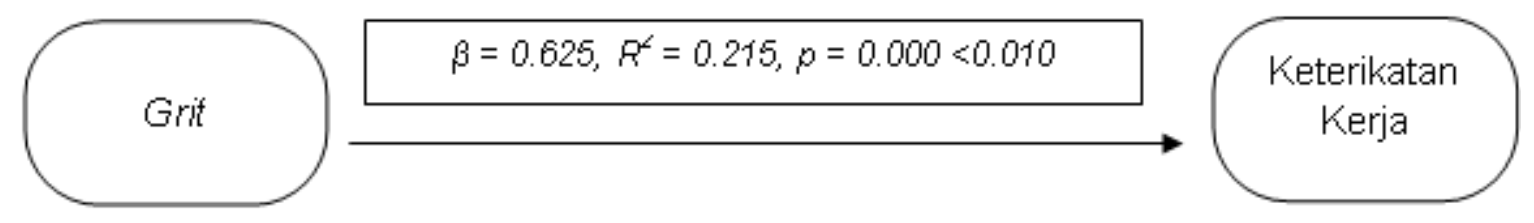

Gambar 1. Hasil uji regresi grit dengan keterikatan kerja

Prosedur analisis uji hipotesis kedua untuk mengetahui peranan kualitas kehidupan kerja terhadap keterikatan kerja juga dilakukan uji regresi menggunakan metode regresi linear diperoleh nilai $\beta=$ 0.625 dengan signifikansi $\mathrm{p} \leq 0.01$. Hal ini menunjukkan bahwa terdapat peranan kualitas kehidupan kerja terhadap keterikatan kerja. Dari hasil uji regresi juga diperoleh nilai $\mathrm{R}$ sebesar 0.540 dan koefisien determinasi $\mathrm{R}^{2}$ ( $\mathrm{R}$ square) sebesar 0.292. Hal ini menunjukkan bahwa kualitas kehidupan kerja memberikan sumbangan peranan sebesar $29.2 \%$ terhadap keterikatan kerja. Kualitas kehidupan kerja yang dimiliki oleh para pekerja millennial yang ada di industri perbankan di Indonesia mempengaruhi keterikatan kerja yang mereka miliki.

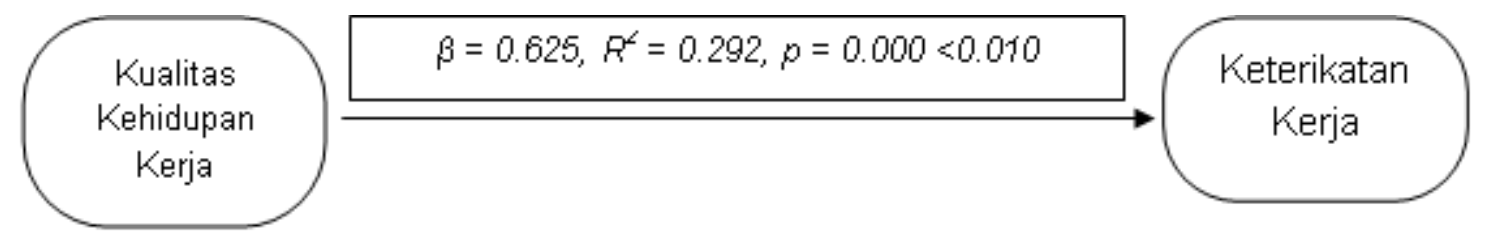

Gambar 2. Hasil uji regresi kualitas kehidupan kerja dengan keterikatan kerja

Uji regresi dengan metode regresi linear juga dilakukan untuk prosedur analisis hipotesis ketiga yaitu untuk mengetahui peranan grit dan kualitas kehidupan kerja terhadap keterikatan kerja. Hasil dari analisis diperoleh hasil bahwa nilai regresi variabel grit terhadap keterikatan kerja dengan nilai $\beta=0.479$ dan kualitas kehidupan kerja terhadap keterikatan kerja memperoleh nilai $\beta=0.527$ dengan signifikansi $\mathrm{p} \leq 0.01$. Hal ini menunjukkan bahwa terdapat peranan grit dan kualitas kehidupan kerja terhadap keterikatan kerja. Dari hasil uji regresi juga diperoleh nilai $\mathrm{R}$ sebesar 0.641 dan koefisien determinasi $\mathrm{R}^{2}$ ( $\mathrm{R}$ square) sebesar 0.411 . Hal ini menunjukkan bahwa grit dan kualitas kehidupan kerja memberikan sumbangan peranan sebesar $41.1 \%$ terhadap keterikatan kerja. Grit dan kualitas kehidupan kerja yang dimiliki oleh para pekerja millennial di industri perbankan Indonesia terbukti mempengaruhi keterikatan kerja yang dimiliki. 


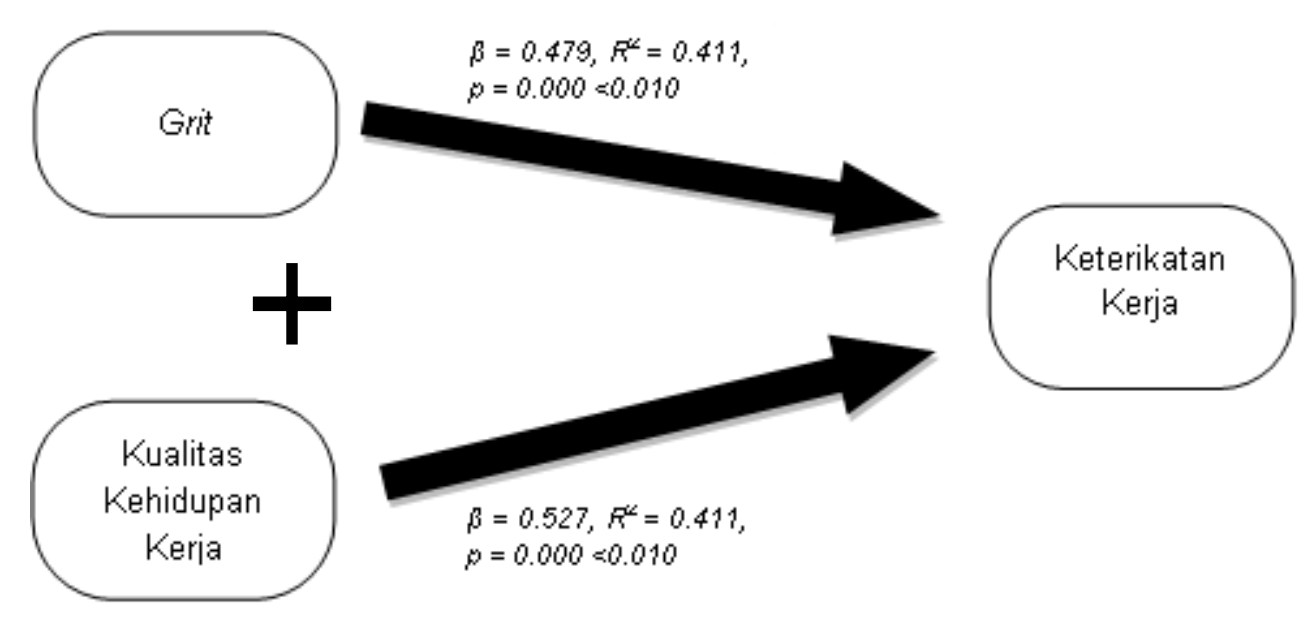

Gambar 3. Hasil uji regresi grit dan kualitas kehidupan kerja terhadap keterikatan kerja

\section{SIMPULAN DAN SARAN \\ Simpulan}

Berdasarkan hasil uji hipotesis didapatkan kesimpulan bahwa ada peranan dari grit dan kualitas kehidupan kerja terhadap keterikatan kerja pada generasi millennial dalam industri perbankan. Hal ini berarti semakin tinggi grit seseorang maka semakin tinggi keterikatan kerja yang dimilikinya dan semakin tinggi kualitas kehidupan kerja seseorang maka semakin tinggi juga keterikatan kerjanya. Sebaliknya, semakin rendah grit maka semakin rendah keterikatan kerja seseorang dan semakin rendah kualitas kehidupan kerja seseorang maka semakin tinggi keterikatan kerjanya. Dengan demikian, hipotesis penelitian ini diterima, sehingga dapat dikatakan bahwa grit dan kualitas kehidupan kerja memiliki peran terhadap keterikatan kerja.

\section{Saran}

Penelitian ini dilakukan dalam industri perbankan baik bank swasta maupun bank pemerintah sehingga diharapkan industri perbankan dapat mulai memperhatikan grit pada masing-masing karyawan terutama pada karyawan generasi millennial karena terlihat bahwa tingkat generasi millennial saat ini memiliki tingkat grit yang cukup tinggi. Perusahaan dapat mengadakan suatu pelatihan untuk meningkatkan grit dari dalam diri masing-masing karyawan, misalnya dengan memberikan tantangan-tantangan baru dalam pekerjaan sehari-hari dan dengan membuat karyawan belajar untuk memiliki harapan ketika keadaan dirasakan menjadi sangat sulit. Atasan masing-masing karyawan juga diharapkan dapat berperan dalam pengembangan grit ini bagi karyawan generasi millenilal khususnya. Hal ini tentunya juga berhubungan dengan kualitas kehidupan kerja yang diharapkan dapat ditingkatkan khususnya dengan diadakannya pelatihan dan pengembangan terhadap keahlian-keahlian yang mendukung pekerjaannya. Peran atasan dalam memberikan kejelasan instruksi juga perlu diperhatikan oleh perusahaan sehingga hal ini juga dapat membantu mendukung kualitas kehidupan kerja karyawan itu sendiri.

Ucapan Terima Kasih (Acknowledgement)

Peneliti mengucapkan terima kasih kepada seluruh partisipan yakni karyawan yang sudah bersedia berpartisipasi dalam penelitian kali ini. 


\section{REFERENSI}

Agyemang, C. B. \& Ofei, S. B. (2013). Employee work engagement and organizational commitment: A comparative study of private and public sector organizations in Ghana. European Journal of Business and Innovation Research, 1(4), 20-33.

Alqarni, S. A. Y. (2016). Quality of work life as a predictor of work engagement among the teaching faculty at king abdulaziz university. International Journal of Humanities and Social Science, 6(8), 118-135.

Badan Pusat Statistik. (2017). Proyeksi penduduk indonesia 2010-2035. http: www.demografi.bps.go.id. Diakses pada tanggal 28 Juni 2017.

Bakker, A.B. (2011). An evidance-based model of work engagement. Current Directions in Psychological Science, 20(4), 265-269.

Christian, M. S., Garza, A. S., \& Slaughter, J. E. (2011). Work engagement: A quantitative review and test of its relations with task and contextual performance. Personnel Psychology, 64 (1), 89-136. doi: 10.1111/j.1744-6570.2010.01203.x

Demerouti, E. \& Cropanzano, R. (2010). From thought to action: Employee work engagement and job performance. In Bakker, A.B. \& Leiter, M.P. (Eds.), Work engagement: A handbook of essential theory and research (pp. 147-163). Hove: Psychology PressDuckworth, A. (2016). Grit: The power of passion and perseverance. New York: Scribner.

Garson, G. D. (2012). Testing statistical assumptions. Asheboro, USA: Statistical Publishing Associates.

Global workforce study. (2014). https://www.towerswatson.com/en-BM/Insights/ICTypes/Survey-Research-Results/2014/08/the-2014-global-workforce-study. Diakses pada tanggal 13 Agustus 2017.

Hewitt. (2008). Leadership Opportunities: Increased Bottom Line Results Through Improve Staff Engagement. Modul.

Kanten, S. \& Sadullah, O. (2010). An empirical research on relationship quality of work life and work engagement. Procedia-Social and Behavioral Sciences, 62, 360-366.

Krisbiyanto, N. (2013). Perjalanan mencari makna engagement bagi organisasi. Human Capital, 290, 112-116.

Lancaster, L. C. \& Stillman, D. (2002). When generations collide: Who they are, why they clash, how to solve the generational puzzle at work. New York: Collins Business.

Putra, Y. S. (2016). Theoritical review: Teori perbedaan generasi. Among Makarti, 9(18), 123134. doi:10.1016/amr.g67p123.

Schaufeli, W.B., \& Bakker, A.B. (2003). UWES-Utrecht Work Engagement Scale: Test manual. Unpublished manuscript. Department of Psychology, Utrecht University, Utrecht, The Netherlands.

Suzuki, Y., Tamesue, D., Asahi, K. \& Ishikawa, Y. (2015). Grit and work engagement: A crosssectional study. PLoS ONE, 10(9), doi:10.1371/journal.pone.0137501

Von Culin, K. R., Tsukayama, E. \& Duckworth, A. (2014). Unpacking grit: Motivational correlates of perseverance and passion for long-term goals. The Journal of Positive psychology. http://dx.doi.org/10.1080/17439760.2014.898320. Diakses pada 13 Agustus 2017.

Worldwide. $13 \%$ of employees are engaged at work. (Oktober, 2013). http://www.gallup.com/poll/165269/worldwide-employees-engaged-work.aspx. Diakses pada tanggal 13 Agustus 2017. 
Yadav, R. \& Khanna, A. (2014). Literature review on quality of work life and their dimension. Journal of Hummanities and Social Science, 19(9), 71-80. http://iosjournals.org. Diakses pada 10 Juni 2017. 